\title{
Małgorzata Jarmołowicz-Dziekońska
}

(Białystok)

\section{EXILIC REPRESENTATION AND THE (DIS)EMBODIED SELF: MEMORY AND PHOTOGRAPHY IN YOSHIKO UCHIDA'S AUTOBIOGRAPHY DESERT EXILE: THE UPROOTING OF A JAPANESE-AMERICAN FAMILY}

\begin{abstract}
Photography and memory seem to be inextricably bound up with each other, as photographs can invoke memories which help to excavate past moments with vivid details. Yoshiko Uchida in her autobiography, Desert Exile: The Uprooting of a Japanese-American Family (1982), delves into her past experiences through the lens of counter-memory, i.e. the memory of the minor and the subjugated. The Japanese-American author strives to recover the past by means of photographic images which-blended into written reminiscencesuncover yet another plane of articulation. Individual memory has enabled the author to chisel her own identity with textual and photographic means of self-expression. Constructing her autobiographical confession, Uchida also draws upon the collective memory of the war internment of the Japanese and Japanese Americans, which inevitably shaped her present self. A set of photographs which accompanies her account testifies that the ocular dimension can be as powerful as the textual one. Each photograph contains a stratum of data which deprives the text of its autonomy and grants it an equal status of signification.
\end{abstract}

Key words: photography, memory, counter-memory, representation, Japanese-American literature 
Photography and memory seem to be inextricably bound up with each other, as photographs can invoke memories which help to excavate past moments with vivid details. They also facilitate bringing particular events into a wider perspective and thus, favour a closer inspection of relationships between the body and the mind, the interior and the exterior. Yoshiko Uchida in her autobiography, Desert Exile: The Uprooting of a JapaneseAmerican Family (1982), delves into her past experiences through the lens of countermemory, i.e. the memory of the minor and the subjugated. The Japanese-American author strives to recover the past by means of photographic images which-blended into written reminiscences - uncover yet another plane of articulation. Since such an endeavour is always scarred by subjectivity (we cannot fully recover the past, only represent it), the image of the self which emerges in the end finds its representation in memory, and thus can be recreated anew. Individual memory has enabled the author to chisel her own identity with textual and photographic means of self-expression. Constructing her autobiographical confession, Uchida also draws upon the collective memory of the war internment of the Japanese and Japanese Americans, which inevitably shaped her present self. A set of photographs which accompanies her account testifies that the ocular dimension can be as powerful as the textual one. Each photograph contains a stratum of data which deprives the text of its autonomy and grants it an equal status of signification. Additionally, the autobiographical genre has provided fertile ground for the development of literary discourse in terms of textual and visual expression.

The significance of photographic image as an expressive means of representation has acquired added value with the advent of autobiographical writing. François Brunet (2013: 90) emphasises the fact that it is "the emergence, in the twentieth century, of a more ambitious discourse and writing effort by 'serious' photographers, which has contributed powerfully to a new understanding of photography as an expressive, indeed often autobiographical medium.” Thus, a new status of photography as a self-expressive mode has enabled its engagement in autobiographical discourse, which evolved into an extended plane of reference for narrative writing. As the critic points out, the urge for 'photographic confessions' at the turn of the century was sparked "by a new awareness of photography as having "made history', especially since the rise of small formats, film, and popular photography after 1890” (92). As a result, traditional self-portraiture has been replaced with a diversity of new expressive forms, such as "multiple and/or serial images, constituting varieties of 
photographic autobiography usually concerned with identities, family narratives, gender roles, ethnic or sexual nonconformity, or disease” (107).

This deflection of the photographic trajectory in terms of representation and agency has promoted an active presence of a discursive ' $\mathrm{I}$ ' in contrast to the sole act of passive observation. According to Brunet (108), the balance has tilted in favour of focusing on active participation involved in the photographic 'performance': “The emphasis therefore shifted from what can be said in photography - either by words or by images - to what is done, happening, or produced in the photographic 'act' or transaction, whether construed as a concreted presence of the photographer or his/her eclipse, voluntary or not.” What is more, as Sean Ross Meehan (2008: 16) expounds, the photographic image embedded in autobiography grants it a dynamic mode of expression which is still in the process of making: "Autobiography, thus figured, is an authentic, autographic image, like a photograph, but the authenticity of this image reflects more a photograph in the dynamic process of emergence, an image unfinished." Therefore, the process of artistic creation does not finish with the accomplished photographic act and a visual product to be viewed. It is also dependent on the eye of the viewer who may survey the image multitudinously in order to create a number of interpretations. The same relationship can be observed with reference to an autobiography as an experience, which Leigh Gilmore (1994: 85) equals to a particular mode of self-expression within cultural and historical contexts. Hence, autobiography as an act of representation is "characterized by a particular act of interpretation: lived experience is shaped, revised, constrained, and transformed by representation. (...) Autobiography describes the textual space wherein the culturally constructed and historically changing epistemology of the self finds particular expression.” Furthermore, in autobiography, the ambiguity of the 'I,' whichaccording to Louis Renza (1980: 279) is translated into 's/he'-lends it a hue of doubleness that results in a bifurcation leading to the private and the public ultimately fused in the narrative act, with the retained autonomy of the author's individuality at the same time: “Autobiographical writing thus entails a split intentionality: the ' $\mathrm{I}$ ' becoming a 'he'; the writer's awareness of his life becoming private even as he brings it into the public domain and putatively makes it present through his act of writing."

Autobiography as a genre constitutes a rich subject to be explored in various directions and a number of interpretations. Georges Gusdorf (1980: 40) delineates its main characteristics emphasising that it "appears as the mirror image of a life, its double more clearly drawn-in a sense of the diagram of a destiny.” With its capability to reflect the past 
subjectively rather than actually mirror it, autobiography holds a valuable asset which can be useful in delving into one's past, since — in fact — the reader plunges into the author's memory and his or her own vision and interpretation of the past. William Howard (1980: 85) goes further and compares autobiography to a self-portrait where the author paints the past from an angle "familiar to himself but not to others."

As a contribution, I will propose a simple analogy: an autobiography is a self-portrait. Each of those italicized words suggests a double entity, expressed as a series of reciprocal transactions. The self thinks and acts; it knows that it exists alone and with others. A portrait is space and time, illusion and reality, painter and model-each element places a demand, yields a concession. A self-portrait is even more uniquely transactional. No longer distinctly separate, the artist-model must alternately pose and paint. He composes the composition, in both senses of that verb; his costume and setting form the picture and also depict its form. In a mirror he studies reversed images, familiar to himself but not to others.

Illustrated autobiography constitutes an even more powerful mode of expression, as it allows the reader to inspect the author's past captured in a visual frame of reference. Employing photographs as visual tools of representation, autobiography translates 'the untranslatable' into tangible images. Where the author is lost for words, a photograph may express the unspeakable: imperceptible feelings or an elusive atmosphere. Nevertheless, it is worth remembering that, according to Jens Ruchatz (2008: 370), a photograph cannot impose only one exclusive rendition of the past, since its meaning is not enclosed within one designated space of signification: "Neither photography as a medium nor a single photograph can be tied down exclusively_or even ontologically_to one exclusive mode of signification.” Therefore, we should also take into account the fact that an act of interpretation and explanation is always left to the author or the observer: "Photography produces an exceptional class of traces, insofar as they are regularly and intentionally produced as well as conventionally recognized as significant and signifying: Photographs show-but do not explain—what has caused them” (370).

Apart from its personal and historical value, autobiography undoubtedly renders an artistic touch to the events and facts it represents. Therefore, as Gusdorf (1980: 43) points out, its significance should "be sought beyond truth and falsity, as those are conceived by simple common sense.” In his view, historical accounts should not overshadow the artistic potential infused into an autobiography, since it holds its own stylistic value: "It is unquestionably a document about a life, and the historian has a perfect right to check out its testimony and verify its accuracy. But it is also a work of art, and the literary devotee, for his part, will be 
aware of its stylistic harmony and the beauty of its images” (43). What also needs to be emphasised is a mutual relationship between a work of literature and an author who creates a piece of writing with a particular purpose in mind. As David Lewei Li (1998: 34) expounds, "literature becomes the transparent repository of experience and the author is its mouthpiece.” Therefore, experience is a common denominator which each time may serve a different purpose for writing, and thus might become a tool for representing and defending various interests: "The integrity and variety of the art form is reduced to its mimetic function, as is the active and complex role of the writer. Art and artist's creativity do not have lives of their own; rather, they depend on the people whose historical and social interests they are assigned to faithfully reflect and serve” (34). This in particular may be observed with reference to autobiographers who speak for minorities, and their works are often the only vent for their muffled voices and emotions which have not had a chance to be revealed to the public and embedded into the mainstream literature. According to Donald Goellnicht (1997: 350), this gap has not been filled due to the dominant culture which has sealed off its homogenous dominion: "Histories, however, have never been absent for long from 'minority' discourses, which have almost always insisted on the presence of the past in the formation of identity or ethnic subjectivity, even though-or because - that past has frequently been ignored or silenced by the dominant culture.”

With the advent and further expansion of critical discourse, autobiographies of AsianAmerican authors are still not commonly investigated, especially in the field of literary criticism. Reflecting their own past seen through the eyes of Others, Asian Americans are ready to speak with a firm voice and willing to be heard. Even though these ethnic writers belong to a minority, they also have their American story to tell. Surprisingly often, it is the story of being misunderstood, rejected and treated as an alien in American society. The major themes of Asian-American writings are fuelled by ambivalent feelings resulting from frequently painful experiences and hardships. For these reasons, as Shirley Geok-Lin Lim (1997: 292) indicates, “[f]amily, home, community, origin, loss, dislocation, relocation, racial differences, cross-cultural resistance, second-generation Americanization and assimilation, identity destabilisation and reformulation, as in many other American ethnic texts, are common trajectories in Asian American literature.” Although this literature does not form the main tissue of the mainstream literary criticism, it is noticeable that with time it is growing into a significant, and-hopefully-more and more visible body of representation. Nevertheless, it cannot be denied that there is still much to be done in this field and what 
remains obvious is that the disproportion needs to be cleared out, since-in Helen Zia's words (2001: x) - the Asian Americans in the United States forming "a community as large, diverse, and dynamic (...) cannot stay on the edge of obscurity, frustrated by images that have rendered [them] invisible and voiceless.”

To uncover the past and re-tell a piece of history from the other side has been the task of many contemporary second-generation (Nisei) Japanese-American authors, who have had to come to terms with an issue which several decades earlier imprinted an indelible mark on their minds and identities. The subject matter of internment has gained so much attention among those who have lived through the internment years that Nisei writings have achieved a status of first-hand historical records and memoirs. Paul Spickard (2009: 193) notices the fact that "[a]lthough most of these books are not written by professional historians, they constitute the first body of literature on Japanese Americans to reflect a historical viewpoint.” The authors, as they frequently emphasise, feel obliged to bear witness to successive generations, and what may be termed 'confessional texts and photographs' also provide a wide frame of reference for historical research. With this in mind, Yoshiko Uchida wrote her autobiography Desert Exile: The Uprooting of a Japanese-American Family, which focuses on the internment of her family and thousands of the Japanese and Japanese Americans during World War II. The work, interspersed with familial photographs, gives a textual and photographic testimony to a national hardship suffered at the hands of the U.S. government. It constitutes a personal account which accommodates not only social and historical strata but, as Traise Yamamoto (1999: 104) delineates, also the construction and representation of an identity that has been forged in the aftermath: "While it is crucial to recognize the documentary elements of these texts, it is equally important to recognize that shifting from a social/historical focus to an autobiographical one shifts critical attention from these narratives as straightforward reconstructions of events to constructions of the self within the context of historical, social and material realities.” Thus, the autobiography has widened the perspective of study, as it focuses not only on historical and social facts of the outer world, relevant especially for collective memory, but also delves into another dimension-the author's inner self, which opens up an interior reality, previously uncommon for historians and sociologists. Individual memory, through the significance of 'I,' has gained added value pertaining to the fact that it has allowed authors to reveal their innermost selves. In consequence, this mode of expression has sparked an ontological quest for the human self 
in the literary world, and photographs have enabled autobiographers to make themselves visible on yet another plane of representation.

The prominence of memory within the scope of representation brings into focus another concept which needs a closer examination in terms of its referentiality. The relation between memory and identity has been noticed since the very beginning of empirical studies and an emphasis on experience as the main source of human knowledge. This epistemological ramification has enabled scholars to explore the conceptualisation of identity as an iterative process which Astrid Erll (2008: 6) subsumes under the category of a continuous selfreconstruction on the past-present axis: "That memory and identity are closely linked on the individual level is a commonplace that goes back at least to John Locke, who maintained that there is no such thing as an essential identity, but that identities have to be constructed and reconstructed by acts of memory, by remembering who one was and by setting this past Self in relation to the present Self.” The same stance finds its reflection in Jan Assmann's view (2008: 113) where the concept of identity is also closely related to past memories, and constitutes a relevant part of cultural memory. What is more, its construction can be viewed only through the lens of temporality, since it relies on facts which are nota bene remembered and reclaimed by the self. Therefore, in this context, the past is shaped solely by one's own reminiscences:

The cultural memory is based on fixed points in the past. (...) Not the past as such, as it is investigated and reconstructed by archaeologists and historians, counts for the cultural memory, but only the past as it is remembered. Here, in the context of cultural memory, it is the temporal horizon of cultural memory which is important. Cultural memory reaches back into the past only so far as the past can be reclaimed as 'ours.' This is why we refer to this form of historical consciousness as 'memory' and not just as knowledge about the past. Knowledge about the past acquires the properties and functions of memory if it is related to a concept of identity.

With this in view, Barbara Misztal (2003: 14) argues that "memory and temporality cannot be detached from each other" on account of the fact that they determine the process of identity formation both on an individual and collective level. Hence, bearing in mind "the old sociological assertion that the present influences the past, it can be said that the reconstruction of the past always depends on present-day identities and contexts” (14). As a result, the selectivity of our recollections recovered from the past reveals much about our present mental state and our cognitive 'proclivity' which obstructs the faithful reflection of past events. As Birgit Neumann (2008: 333) asserts, this is due to the fact that "our memories are highly selective, and that the rendering of memories potentially tells us more about the rememberer's 
present, his or her desire and denial, than about the actual past events.” The photograph may assume a similar role, bringing into light only those subjects which, according to the photographer, need to be rendered in a proper magnitude, whereas others are destined to be omitted and cast into oblivion. Thus, selectivity may work in both directions, partially retrieving both verbal and visual remnants of the past.

Due to the fact that, as previously stated, autobiography cannot be treated in its entirety as "simple repetition of the past as it was, for recollection brings us not the past itself but only the presence in spirit of a world forever gone” (Gusdorf 1980: 38), Uchida takes us to the world which can be recognised only through her eyes. What needs to be mentioned at this point is an issue of referentiality of the author to the past. As Gusdorf explicates, the autobiographer never remains independent of his or her own subjective reminiscences and always returns to a moment in the past with an altered consciousness, maturity, experience, etc. Thus, while excavating the past, the author may apply a lens of different magnitude and each time produce a modified vision of the same past event:

Recapitulation of a life lived claims to be valuable for the one who lived it, and yet it reveals no more than a ghostly image of that life, already far distant and doubtless incomplete, distorted furthermore by the fact that the man who remembers his past has not been for a long time the same being, the child or adolescent, who lived the past. The passage from immediate experience to consciousness in memory, which effects a sort of repetition of that experience, also serves to modify its significance (38).

Without doubt, memory becomes an indispensable token of identity especially at a collective level. As collective, or social, memory, it translates-according to Misztal's definition (2003: 158) —into “a group's representation of its past, both the past that is commonly shared and the past that is collectively commemorated, that enacts and gives substance to that group's identity, its present conditions and its vision of the future.” The systematic study of the conceptualisation introduced by Maurice Halbwachs in 1925 delineated that an individual's understanding and interpretation of the past draws heavily on group's consciousness. In other words, people shape their collective memory by selecting what should be remembered. Constituting "the essential anchor of particularistic identities" (Misztal 2003: 133), social memory is an amalgam of multitudinous identities which exist on the same plane of reference. With a common purpose of representation, each group of people is supposed to speak with its own voice; however, it is not always the case. There are minorities whose voices are not taken into account or even not granted entry into mainstream discourse. As Paul Shackel (2001a: 3) phrases it, they are thwarted by major collective 
memories, which may yield a number of negative results: "While collective memory can be about forgetting a past, it often comes at the expense of a subordinate group. Those who are excluded may try to subvert the meaning of the past, or they may strive for more representation in the form of a more pluralistic past. Sometimes they may not even call attention to their absence in the collective memory.” In consequence, as the author continues, the disregarded find themselves trapped in a meaningless void of non-signification, which breeds either passivity or a strenuous effort to make themselves noticed: "Remembering a particular past often means that there are those in subordinate groups who must either find strategies to exist within the dominant interpretation of the past, or struggle to get their views assimilated into the collective memory” (2001b: 17). Regrettably, too often not having succeeded, their reminiscences are doomed to oblivion. Shackel (2001a: 4) observes that such a conjuncture is frequently an integral part of a common literary landscape: "We often find that while accounts of ordinary people and subaltern groups do not necessarily find their way into official accounts, they do become part of the private memory.” Their unobtrusive narratives, hidden from sight, still wait to be discovered by the public eye. Asian Americans are one of these groups which, as the scholar argues, due to their subordinate status are fated to "live in a state of 'two-ness.' They must exist within the dominant culture, where the meaning of the landscape is controlled by a dominant group. In some cases they are reasserting the right to give their own meaning and history to sacred objects and landscapes, and in other cases they are ignoring their lack of representation” (2001b: 19). By no means, this dichotomy of representation creates a distorted image of history where only one party is given voice to provide its personal accounts of past events.

In order to remedy the disproportion between mainstream and minority literatures, and what follows, to harness master narratives of the past, there has been delineated another potential source of memory which - in opposition to the enforcement of supreme narrationsexhorts the public eye to notice less discernible accounts of the past. Counter-memory which appeared as a counter-proposal to the existing major narratives has been termed by Misztal (2003: 158) as "an alternative view of the past which challenges the dominant representation of the past.” Therefore, the narrator assumes her or his own position from which events are going to be narrated. Viewed from such a perspective, as Vita Fortunati and Elena Lamberti (2008: 129) explicate, “the term 'counter' emphasizes the fact that these are other memories belonging to minority groups and thus marginalized by the dominant cultures. Memory becomes an 'act of survival,' of consciousness and creativity, fundamental to the formation 
and rewriting of identity as both an individual and a political act.” The origins of the concept can be traced back to Michel Foucault (1977: 160), who-with a view to challenge official narrations of the past—defines a 'counter-memory’ as “an individual's resistance against the official versions of historical continuity." Within this paradigm, Asian-American literature can find its own space to proclaim its autonomy. Silenced no more, it is able to 'counter-act', and with its marginal voices which are noticeable worldwide more and more increasingly, form its own narration of the past. Hence, according to Ann Rigney (2008: 348), such narrative writings have a chance to come into existence "as a privileged medium of oppositional memory, as a 'counter-memorial' and critical force that undermines hegemonic views of the past.” Their purpose is to reveal another discursive plane where bipolar voices are equalled in their potency and resonate with the same force, since-as Misztal (2003: 65) points out- "the discourse of struggle is not opposed to the unconscious, but to the secretive, hidden, repressed and unsaid." The same measure could be applied to the photograph as a discursive means of representation. Some images do not enter the world of the mainstream, often non-ethnic, national paradigm. The lens of interpretation are adjusted by master narratives which dominate a national landscape of the media, culture, etc. For this reason, it is difficult to see through this tightly-knit veil of ignorance and discern other bodies of representation which linger in the distance in the hope of being recognised and acknowledged.

As there are good reasons to assume that memory lays the foundations for identity, this leads us to the concept of autobiographical memory, which Misztal delineates as a "memory about the self that provides a sense of identity and continuity. It is a source of information about our lives, as we reconstruct the past when telling others and ourselves the story of our life” (158). Inevitably, an autobiography unveils the most of the author but, at the same time, only to a degree where a demarcation line has been drawn. This boundary of privacy allows the author to maintain a private profile in the public domain. Harald Welzer provides a more complex explication, emphasising that autobiographical memory brings into perspective not only a dimension of the inner self but also a reflection of the self perceived with the eyes of other people over time. Thus, the two planes of reference enable the autobiographer to inspect her or his inner profile with two disparate vectors of representation, however viewed and interpreted through the same subjective lenses of the author:

The autobiographical memory is just such a relay, a psycho-social entity that subjectively safeguards coherence and continuity even though the social environments and thus also the requirements demanded of the individual fluctuate. (...) Autobiographical memory allows us not only to mark memories as our memories; it 
also forms the temporal feedback matrix of our self, with which we can measure where and how we have changed and where and how we have remained the same. It also offers a matrix which allows us to coordinate the attributions, assessments, and judgments of our person that our social environment carries out almost ceaselessly (Welzer 2008: 292).

Ethnic autobiographical literature holds another significant feature which makes it worthwhile to be explored. It furnishes the reader with a conviction that an autobiography renders the past without imposed frames of interpretation and hence, precludes the author from distorting a personal image of her/himself. An autobiographical work, providing a first-hand account of past events, also constitutes an invaluable source of background information. Therefore, as Elaine Kim (1982: xviii) underscores, “[b]y studying Asian American literature readers can learn about the Asian American experience from the point of view of those who have lived it.” Photographs embedded in a personal story make it an even more powerful mode of expression, which in a way amplifies its ultimate message and fulfils the primary objective of those who desire to be heard.

Uchida's autobiography presents a hybrid combination of textual and visual representation, which blends into a poignant testimony of ethnic rejection and, in this way, refuses to be consigned to oblivion. Photographic images that intersperse the text correspond precisely to the time frame, in which the author's life is inserted. The chronological sequence of the photographs enables the viewer to follow ensuing events along with Uchida's story. Beginning with reminiscences of her early childhood years, the author traces her family's history back to the times before her parents met. Thus, the autobiography becomes a chronicle of events spanning two generations of her family that prevailed regardless of adverse circumstances.

Deeply rooted in Japanese minds, the tradition of taking photographs to immortalise significant occasions and highlight strong family bonds has been present throughout Uchida's whole life, which finds its reflection in her autobiography that might have been incomplete without those tokens of respect and appreciation. The author leads the reader into her family's life almost from the very beginning of her existence. The photograph of a three-year-old Yoshiko and her elder sister, Keiko, who were born out of an arranged marriage, starts the black-and-white pictorial saga of the Uchidas in the United States (Uchida 1982: 13). Posing with an open book, the girls - in a composed manner - seem to favour the Japanese reverence for education, which finds a further reflection in a group portrayal of the members representing "the congregation and Sunday School of the Japanese Independent 
Congregational Church of Oakland, about 1928” (33). The next photographs feature the family house in Berkeley and the sisters in their childhood and adolescent years, posing with the beloved dog, Laddie. As the author recollects, "there was nothing particularly unusual about our living there except that we were Japanese Americans. (...) It seemed the realtors of the area had drawn an invisible line through the city and agreed among themselves not to rent or sell homes above that line to Asians” (3-4). Unfortunately, the discrimination against the Japanese and Japanese Americans reached far beyond that. They felt alienated on every plane of their everyday existence and condemned to menial work throughout their lives.

Their family life goes on unrestrained until a dramatic turn of events which profusely aggravates a living situation of every Japanese and Japanese American on the West Coast. After the bombing of Pearl Harbor by the Japanese Navy on $7^{\text {th }}$ December 1941, the United States declared entering World War II. This bred profuse political ramifications for all people of Japanese ancestry. Within a few days, the FBI agents and law-enforcement officers knocked on the door of every Japanese-American family, arrested Uchida's father and "dozens of other Japanese men. Executives of Japanese business firms, shipping lines, and banks, men active in local Japanese associations, teachers of Japanese language school virtually every leader of the Japanese American community along the West Coast had been seized almost immediately” (46). Uchida recalls the detention of her father as a particularly disturbing experience: “Without Papa things just weren’t the same, and none of us dared voice the fear that sat like a heavy black stone inside each of us” (47). Soon, they were to witness and experience a period which extended beyond their imagination. What followed had by far more severe and further reaching consequences.

The successive countermeasure taken afterwards included unprecedented tactical manoeuvres. On $19^{\text {th }}$ February 1942, President Roosevelt issued Executive Order 9066, which empowered the Secretary of War to designate areas from which 'any and all persons' would be soon excluded. Uchida expounds that the directive was aimed at one nationality, which from the very beginning ostracised only the Japanese ethnic background: “Although use of the word 'Japanese' was avoided in this order, it was directed solely at people of Japanese ancestry. The fact that there was no mass removal of persons of German or Italian descent, even though our country was also at war with Germany and Italy, affirmed the racial bias of this directive” (56). What is more, the most disturbing and irrational aspect of the whole undertaking was the average age of the evacuees who turned out to be beyond the military service age, which made the purpose of the evacuation even more nonsensical. According to 
Michi Weglyn (1991: 423), “[o]ne of the gross absurdities of the evacuation was that a preponderance of those herded into wartime exile represented babes-in-arms, school-age children, youths not yet of voting age, and an exhausted army of elderly men and women hardly capable of rushing about carrying on subversion. The average age of the Nisei was eighteen. The Issei's average age hovered around sixty.” Thus, as Lauren Kessler (1994: 176) emphasises, it became obvious, however not voiced loudly, that the decision was premised only on Japanese nationality: “[t]he real target was the ethnic Japanese, the people who had the same face as America's new enemy. (...) How could this government (...) treat some of its citizens differently from others, merely because of their parents' birthplace?”

The beginning of the period of hatred is highlighted by Uchida with a photograph of newspapers, displayed on the newsagent's rack, with front pages yelling in capital letters: “OUSTER OF ALL JAPS IN CALIFORNIA NEAR!” (Uchida 1982: 55). In the caption below, the author informs that the scale of animosity was significantly magnified by the media: “[i]n 1942, hatred against the Japanese Americans was fueled by newspapers that usually referred to us as 'Japs'. ” In such a way, as the author continues, these "shabby efforts by irresponsible and inflammatory statements by the radio and press" linked the Japanese to threatening entities, which was supposed to conjure up "the enemy in the public mind" (53). In fact, the media had no boundaries in generating falsehoods against the Japanese 'foes':

They also circulated totally unfounded stories. The Japanese Americans, they reported, had cut arrows in the sugar cane to guide the Japanese bombers to Pearl Harbor; they had interfered with vital United States communications by radio signals; they were treacherous, and loyal only to the Emperor of Japan; they had used their fishing boats to conduct espionage. So completely were these falsehoods accepted by the public that I have heard some of them repeated even today by those who still believe the forced removal of the Japanese Americans was justified (53-54).

All these operations led to a destructive result which imprinted its mark on the Japanese in the United States and the following generations of Japanese Americans. Drastic measures which were taken subsequently triggered a relocation on a massive scale: "By the middle of March, Lieutenant General John L. DeWitt began to execute the order and set in motion the removal from Military Area Number One, along the entire West Coast, of over 120,000 men, women, and children of Japanese ancestry, the majority of whom were American citizens" (56). They were allowed to move beyond the perimeters of the designated military zone on a voluntary basis, which triggered a fractional response: "some 10,000 made their own way outside the excluded zones, while the remaining 110,000 were incarcerated" (56). The entire idea of the evacuation in such a manner was doomed to failure from the very 
beginning, since it required an extraordinary effort at a smooth transition, which was impracticable due to an extremely brief period of notification:

We were told by the military that 'voluntary evacuation' to areas outside the West Coast restricted zone could be made before the final notice for each sector was issued. The move was hardly 'voluntary' as the Army labelled it, and most Japanese had neither the funds to leave nor a feasible destination. (...) We decided, finally, to go the government camp where we would be with friends and presumably safe from violence. We also hoped my father's release might be facilitated if he could join us under government custody (58).

The period of the forthcoming interment documented in the following photographs starts with a depiction of the Japanese and Japanese Americans waiting in queues to be relocated (65). Beforehand they were mandated to observe certain regulations in order to comply with the governmental measures: "A five-mile travel limit and an 8:00 P.M. curfew had already been imposed on all Japanese Americans since March, and enemy aliens were required to register and obtain identification cards” (58). Uchida informs in the caption that "[b]aggage was a major problem, for we were told to take into camp only what we could carry” (65). The evacuees were allowed to pack bedding and linen, toilet articles, extra clothing and cutlery. Permission for taking only two suitcases meant that the task of packing verged on the impossible: "Although we had been preparing for the evacuation orders, still when they were actually issued, it was a sickening shock. (...) Mama still couldn't seem to believe that we would have to leave. 'How can we clear out in ten days a house we've lived in for fifteen years?' she asked sadly” (59). In Uchida’s view, more clear-cut instructions would have prevented them from despair in such unfavourable circumstances: "We could have been spared our anxiety and agonizing had we known trucks would be available to transport our baggage to camp. But it is entirely possible the omission of this information in our instructions was intentional to discourage us from taking too much baggage with us” (64).

The Uchidas, due to Exclusion Order Number Nineteen, were obliged to relocate to the Tanforan Assembly Center in San Bruno, which in fact was "a hastily converted racetrack” (59). After registration, they received name tags with a family number, which had to be attached to all their belongings. The author emphasises depersonalisation that ensued as a result of such impersonal treatment: "From that day on we became Family Number 13453" (59). In the same way, all the interned families became anonymous cogs in the American social machine. This dissociation gave rise to other misconceived actions which aggravated their predicament to a greater extent. The day of the relocation sank deeply in Uchida's memory. The photograph depicting a crowded group of the internees waiting to embark 
a relocation coach makes them fade into the distance to the advantage of the U.S. military service in the foreground (66). The soldiers armed with rifles are inspecting the incoming people and supervising each activity, to the horror and consternation of the young Yoshiko: “It wasn't until I saw the armed guards standing at each doorway, their bayonets mounted and ready, that I realized the full horror of the situation. Then my knees sagged, my stomach began to churn, and I very nearly lost my breakfast” (67). However, a deeper disappointment was yet to ensue from the events of the day. When the journey to their destination came almost to an end, the dark silhouette of the camp began linger in the distance: "As we rode down the highway, the grandstand of the Tanforan racetrack gradually came into view, and I could see a high barbed wire fence surrounding the entire area, pierced at regular intervals by tall guard towers. This was to be our temporary home until the government could construct inland camps far removed from the West Coast” (67). The irreversibility of the moment made it even harder to digest, since Yoshiko knew that this was to become her home place for an indefinite period of time: "I saw armed guards close and bar the barbed wire gates behind us. We were in the Tanforan Assembly Center now and there was no turning back” (68).

The subsequent photographs present the stark reality of the internment camp. A barrack alongside a ditch over which planks have been hastily flung to allow the passage to the doorway does not resemble a place suitable for permanent residency (73). As Uchida mentions in the caption, her whole family "lived in a single horse stall in an old stable at the Tanforan racetrack” (73). Explicating further, the author delineates the fact that this interim arrangement had been miscalculated since its incipience, as its temporary measures did not provide sufficient conditions for living: "Nothing in the camp was ready. Everything was only half-finished. I wondered how much the nation's security would have been threatened had the Army permitted us to remain in our homes a few more days until the camps were adequately prepared for occupancy by families” (70). This bitter view gets enhanced with time, as her life at the camp becomes more and more arduous. The photograph of communal meals, with the evacuees crowding to get their portions, has been captioned: "Long lines of internees, clutching their own plates and eating utensils, formed outside the Tanforan mess halls for each meal” (74). The entire process of distributing food made Uchida feel deprived of not only her family's home but also her human dignity, which was aggravated by the unbearable reflection of sorrow written all over her mother's face: “As we stood in what seemed a breadline for the destitute, I felt degraded, humiliated, and overwhelmed with a longing for 
home. And I saw the unutterable sadness on my mother's face. This was only the first of many lines we were to endure, and we soon discovered that waiting in line was as inevitable a part of Tanforan as the north wind that swept in from the bay stirring up all the dust and litter of the camp” (71). What is more, the lack of personal space, "with semi-private cubicles provided only for sleeping” (75), made it impossible to enjoy the previous familial lifestyle, which started to breed inevitable consequences for the young teenager:

After three months of communal living, the lack of privacy began to grate on my nerves. There was no place I could go to be completely alone-not in the washroom, the latrine, the shower, or my stall. I couldn't walk down the track without seeing someone I knew. I couldn't avoid the people I didn't like or choose those I wished to be near. There was no place to cry and no place to hide. It was impossible to escape from the constant noise and human presence. I felt stifled and suffocated and sometimes wanted to scream. But in my family we didn't scream or cry or fight or even have a major argument, because we knew the neighbors were always only inches away (96).

The predicament of the Uchidas gets hardly better after their relocation to another internment camp, the Central Utah Relocation Center, which-according to Uchida— "was another wrench, another uprooting, and this time we were bound for an unknown and forbidding destination” (103). Topaz , called the 'city of dust,' turned out to be “one of ten such camps located throughout the United States in equally barren and inaccessible areas” (106). The photograph of the barracks taken from the distance presents a bird's eye view of the camp, "a cluster of dusty tar-papered barracks in the bleak Sevier Desert. Hidden from view are the barbed wire fence and the guard towers" (107). In fact, high-alert security constituted the essential pillar of the camp’s existence. Spickard (2009: 116) delineates the fact that no activity could be performed without surveillance:

No one could go outside the barbed wire except for extreme medical emergencies, and then they went under guard. Friends could visit and sometimes did. Though the inmates' former homes might be only a few blocks or miles away, the guard towers, machine guns, guard dogs, searchlights, and fences reminded them that they were prisoners. The daily regimentation reinforced that awareness. There was a roll call in the mess hall each morning. At night there was a curfew, and the inmates were counted again.

Interestingly, the internees were informed that increased vigilance was due to their threatened security. Zia (2001: 42) makes this point in a more straightforward way, emphasising the fact that "the families were told they needed barbed wire and armed guard towers for their own protection—but the guns pointed inward.”

This brings us to the issue of body, since the internees were denied their freedom and clustered in camps where not only their mental capacity was harnessed but also their bodies 
were subjected to the infliction of physical distress. Linda Haverty Rugg (1997:14) emphasises that photographs make the experiences of the Japanese Americans the focal point and a referential plane for their autobiographies: "The integration of photographs into the autobiographical act highlights the presence of the author's body, and seems to claim the body as the source and focus of the biographical text.” What is more, Yamamoto (1999: 106) points out that camp narratives are personal testimonies of subjects who were bereft of writing their own life scenarios and, as a result, shaping their own personalities realised through an act of imposed inferiority: “While these narratives function as records of 'day-to-day' life in the camps, they are also the statement of a subject whose constitution is intimately tied to the fact of the internment. To write about the internment is to write about an event whose very basis was the denial of subjectivity, and it is thus an act of writing the self-and by extension the community of interned Japanese Americans - as subject.” With the advent of photography, the subject matter of body can be perceived in a twofold way. In Rugg's view (1997: 13), photographs 'multiply' the singularity of the author and, at the same time, create a unified image of the self:

The insertion of photography (either as object or metaphor) into an autobiographical text can thus cut both ways. On the one hand, photographs disrupt the singularity of the autobiographical pact by pointing to a plurality of selves; not only this image but this one, this one, and that one are the author. On the other hand, photographs in an autobiographical context also insist on something material, the embodied subject, the unification (to recall the autobiographical pact) of author, name, and body.

As Rugg continues, the problem of referentiality delves much deeper into the ontological core of the subject: “Autobiography, like photography, refers to something beyond itself; namely, the autobiographical or photographed subject" (13). This points to a two-dimensional resolution in terms of representation. According to the critic, photographs can attest to visualising the self either in a disintegrative or reintegrative act: "While the autobiographical act, whether textual or photographic, begins with a disassociation (the self's observation of the self as other), I will argue that the introduction of photographs into autobiography not only effectively represents that disassociation but also offers a possibility of reconciliation or reintegration” (14). What emerges within this framework is the fact that, as Yamamoto (1999: 113-114) reasons, "Nisei women enter the discursive field of autobiography already conscious of themselves as split subjects. (...) What before the war had been an awareness of participating in two cultures became during and after the war a split self. (...) The bifurcation of self is a theme that runs throughout all Nisei autobiographies. That is to say, both women and men experience this same sense of being split.” This observation brings into focus 
a perspective of representation in terms of particular cognitive content which autobiographers are supposed to provide for the public opinion. Delineating that "the human body is made to perform as a representative of a cultural and political agenda, and thus loses its power to represent an individual and the individual's integrity,” Rugg (1997: 205) exposes the vital role of minority autobiographies which strive to gain their own voice and hence, their authors become 'disembodied' for the sake of the unified articulation, against the mainstream pressure. The disembodied selves attempt to establish the central ground of attention for the common recognition of their cultural and historical accounts. A specific vantage point taken by each ethnic group may be, as the critic convinces, a springboard for critical discourse: "Where autobiographies come from, the physical, cultural, and historical position from which they emerge, occupies a central place in discussions of women's and minority autobiography” (16). Concurrently, it needs to be remembered that their culturally characterised bodies are in a constant search for their inner selves, and therefore require referential points provided not by superior powers but embedded within their own ethnic planes of reference:

The need for a continued assertion of autobiographical referential power is perhaps most obvious in studies of women's and minority autobiography, which deal with the culturally defined bodies of their autobiographical subjects. While the concept of 'body' in such studies refers more to multiple cultural and historical constructions of bodies than a monolithic and independent physical entity, there is nevertheless an insistence on coming to grips with the self in the world" (10-11).

All in all, photography_as Rugg infers_positions the writing self in a double-set environment, represented by culture and a tangible image of the body: “Thus the presence in autobiography cuts two ways: it offers a visualization of the decentered, culturally constructed self; and it asserts the presence of a living body through the power of the photographic referentiality" (19). With this double means of representation the autobiographer is able to construct her or his identity in a panoramic view which encompasses not only the immaterial but also the corporeal self.

The period of the internment is brought to an end with the photograph of the Uchidas on the camp premises at Topaz on the day of their "departure for the outside world" in 1943 (Uchida 1982: 143). Leaving the makeshift assembly centres, the Japanese Americans had no reasonable means of survival to look for, as hostility towards them was still rife in American society. Apart from lost businesses and dilapidated houses, a bleak future was the only certainty which awaited them with open arms. Spickard (2009: 144) explicates that the reverberations of the internment imprinted an indelible mark on Japanese-American 
communities, since "the concentration camp episode had led to a precipitous decline in Issei power and authority, with few members of the next generation, ready to take over; dissolution of community institutions; economic disarray; and psychic damage to the Nisei generation.” The eldest generation received the most severe blow, after which it was unable to restore its previous working capacity. As Kim (1982: 19) contends, “[t]he most disruptive effects of that internment were felt by the older issei (first generation) men, many of whom had passed the prime of their lives at the time of internment and were never able to recover the loss of everything they had worked for.” Even more disquieting is the fact that racial discrimination seems to be the only viable reason for instituting such drastic measures by the U.S. government. According to Uchida (1982: 57), the entire evacuation was not carried out in compliance with the law: "Both the Fifth and Fourteenth Amendments to the Constitution providing for 'due process of law' and 'equal protection under the law for all citizens,' were flagrantly ignored in the name of military expediency, and the forced eviction was carried out purely on the basis of race.” In fact, as Spickard (2009: 108) emphasises, the internment constitutes an unprecedented period in the U.S. political history: "This mass movement of people into concentration camps was not unusual in U.S. dealings with Native Americansthe Cherokee Trail of Tears in 1838-1839 and the Navajo Long Walk in 1864 are just two examples. But the incarceration of Japanese Americans had no twentieth-century precedent.” Most importantly, it has been stated that all the accused Japanese Americans were acquitted of the presumed wrongdoings, so the whole mystification turned out to be premeditated by the government. Kessler (1994: 118) points out that "[t]hese were not people who had been or would ever be formally accused of acts of disloyalty, espionage or sabotage. These were people, as one nisei later wrote, whose 'only crime was their face.' In fact, no person of Japanese ancestry living in the United States, Alaska or Hawaii was ever charged with or convicted of any act of espionage or sabotage during the entire World War II period.” Uchida (1982: 146) subsumes the aforementioned period under one of the most ignominious failures of the U.S. government, since it undermined the essential principles of democracy and, as a result, betrayed all the citizens of the country:

Our wartime evacuation is now history and has been judged one of the most shameful episodes in our country's past-indeed, one of its most egregious mistakes. The ultimate tragedy of that mistake, I believe, was that our government betrayed not only the Japanese people but all Americans, for in its flagrant violation of our Constitution, it damaged the essence of the democratic beliefs on which this country was founded. The passage of time and the emergence of heretofore unpublished documents have revealed to us today the magnitude and scope of that betrayal. 
In the end, President Ronald Regan officially recognised the gravity of the misconduct and admitted it had been a mistake. Greg Robinson 2015: 54 concludes that "[t]he redress movement lasted nearly two decades and ultimately triumphed in the Civil Liberties Act of 1988, under which Congress issued an official apology and awarded \$20,000 redress payment to each surviving former inmate.” Kessler (1994: 276) compares the whole episode to a dramatic effort which was finally rewarded with due justice: “The winning of reparations was in many ways the nisei's swan song. They had proved to themselves and to their children that they could stand up for their rights.”

The last photograph in Uchida's autobiography is a confirmation that the family's life returned to normal, at least 'normal' in terms of unrestricted freedom. A post-war reunion with the author's grandmother on her eighty-eight birthday in Los Angeles, 1950 (Uchida 1982: 151), depicts radiant smiles present on everyone's faces and an almost tangible sensation of relief lingering in the air. However, the Uchidas' existence did not resemble their previous lives anymore. The wounds had taken a long time to heal, especially in the case of the eldest family members who had to bear the brunt of ramifications which ensued afterwards: "it was largely the Issei who had led the way, guiding us through the devastation and trauma of our forced removal. (...) During the war, (...) they all suffered enormous losses, both tangible and intangible. The evacuation was the ultimate of the incalculable hardships and indignities they had borne over the years. And yet most of our parents had continued to be steadfast and strong in spirit” (142). In fact, it is the attitude of her parents that taught Uchida resilience devoid of resentment. Their positive outlook on life prevented her from taking the path of simmering rancour and malaise, which otherwise might have led to devastating results:

Like many other Issei, my parents made the best of an intolerable situation. Throughout their internment they maintained the values and faith that sustained them all their lives. They continued to be the productive, caring human beings they had always been, and they continued always to have hope in the future. They helped my sister and me channel our anger and frustration into an effort to get out of camp and get on with our education and our lives. They didn't want us to lose our sense of purpose, and I am grateful they didn't nurture in us the kind of soul-decaying bitterness that would have robbed us of energy and destroyed us as human beings. Our anger was cathartic, but bitterness would have been self-destructive. (...) Looking back now, I think the survival of the Japanese through those tragic, heartbreaking days was a triumph of the human spirit (148-149).

It is also important to remember that minority autobiographies have had more obstacles to overcome in their attempt to reach wider audiences. In this case, as Goellnicht (1997: 352) asserts, the voice of minorities in literature is a means of survival and marking of 
their existence: “for 'minorities' written out of 'official' history, recorded memory is not a luxury, an academic exercise, but the very proof of existence: 'we were/are here.' Again and again in these texts, the act of re-membering, of putting fragments back together, of reclaiming the body (of flesh, history, and memory) is presented as essential for survival.” Concurrently, the critic exhorts their common presence in mainstream discourse in order to establish their due positon in the world that is still too homogeneous: "Words must flow if 'minority' individuals and cultures are to survive and to find voice” (352). Yamamoto (1999: 105) voices her concern more straightforwardly, pointing to the blatant marginalisation of the Japanese Americans in this respect, especially during the internment period. Simultaneously, she sees a hope in the accounts of such historical injustices, which may significantly contribute to the prevention of such acts of mistreatment in the future: "In one sense, speaking as hostilely marginalized subjects whose individuality was denied, much of the impulse driving Japanese American autobiographers involves witnessing a group wrong in order to prevent a recurrence of a historical event, the national memory of which is threatened by the occlusions of time and apathy." In fact, Uchida (1982: 153-154) makes this purpose abundantly clear in her autobiography. Her personal account serves as a teaching tool for the next generations and fills the gap on the literary map of Japanese-American witness testimonies: "Still, there are many young Americans who have never heard about the evacuation or known of its effect on one Japanese American family. I hope the details of the life of my family, when added to those of others, will enhance their understanding of the history of the Japanese in California and enable them to see it as a vital element in that glorious and complex story of the immigrants from all lands who made America their home.”

Although the shameful internment period has been given its proper name and an official apology was delivered on the part of the U.S. government a few decades ago, it does not mean that the time for speaking and listening has ended. As Cathy Caruth (1996: 18) argues, there are many void spaces to be filled and unheard stories to be told. Our task is to channel them into intercultural discourse in order to construct a platform from which every voice will be heard and listened to:

This speaking and this listening - a speaking and a listening from the site of traumadoes not rely, I would suggest, on what we simply know of each other, but on what we don't yet know of our own traumatic pasts. In a catastrophic age, that is, trauma itself may provide the very link between cultures: not as a simple understanding of the pasts of others but rather, within the traumas of contemporary history, as our ability to listen through the departures we have all taken from ourselves. 
In such a way no traumatic testimony will be omitted or obscured. Hence, the ability to listen seems to be the most urgent necessity for present-day literary criticism. Photographs may serve an adjuvant role in recounting the past, as they provide their own reflections of events and subjects. What is more, they are capable of disembodying the text and depriving it of its purportedly neutral cognitive content. Uchida's autobiography, laced with the author's genuinely personal accounts, proves that bridging the gap between image and word can be a successful task in striving to recognise an ethnic contribution towards the reconstruction of memory within the scope of contemporary history.

\section{Bibliography}

Assmann, Jan. 2008. Communicative and Cultural Memory. In A. Erll and A. Nünning (eds). Cultural Memory Studies: An International and Interdisciplinary Handbook (pp. 109118). Berlin and New York: Walter de Gruyter.

Brunet, François. 2013 [2009]. Photography and Literature. London: Reaktion Books.

Caruth, Cathy. 1996. Unclaimed Experience: Trauma, Narrative and History. Baltimore MD: Johns Hopkins University Press.

Erll, Astrid. 2008. Cultural Memory Studies: An Introduction. In A. Erll and A. Nünning (eds). Cultural Memory Studies: An International and Interdisciplinary Handbook (pp. 1-18). Berlin and New York: Walter de Gruyter.

Fortunati, Vita and Elena Lamberti. 2008. Cultural Memory: A European Perspective. In A. Erll and A. Nünning (eds). Cultural Memory Studies: An International and Interdisciplinary Handbook (pp. 127-137). Berlin and New York: Walter de Gruyter.

Foucault, Michel. 1977. Language, Counter-memory, Practice: Selected Essays and Interviews. (Ed. by D. F. Bouchard). Ithaca, New York: Cornell University Press.

Geok-Lin Lim, Shirley. 1997. Immigration and Diaspora. In K. Cheung (ed.). An Interethnic Companion to Asian American Literature (pp. 289-311). Cambridge: Cambridge University Press.

Gilmore, Leigh. 1994. Autobiographics: A Feminist Theory of Women's Self-representation. Ithaca and London: Cornell University Press.

Goellnicht, Donald C. 1997. Blurring Boundaries: Asian American Literature as Theory. In K. Cheung (ed.). An Interethnic Companion to Asian American Literature (pp. 338-365). Cambridge: Cambridge University Press.

Gusdorf, Georges. 1980. Conditions and Limits of Autobiography. In J. Olney (ed.). Autobiography: Essays Theoretical and Critical (pp. 28-48). Princeton, New Jersey: Princeton University Press.

Howard, William L. 1980. Some Principles of Autobiography. In J. Olney (ed.). Autobiography: Essays Theoretical and Critical (pp. 84-114). Princeton, New Jersey: Princeton University Press. 
Kessler, Lauren. 1994. Stubborn Twig: Three Generations in the Life of a Japanese American Family. New York: Plume.

Kim, Elaine H. 1982. Asian American Literature: An Introduction to the Writings and Their Social Context. Philadelphia: Temple University Press.

Li, David Lewei. 1998. Imagining the Nation: Asian American Literature and Cultural Consent. Stanford, California: Stanford University Press.

Meehan, Sean Ross. 2008. Mediating American Autobiography: Photography in Emerson, Thoreau, Douglass, and Whitman. Columbia and London: University of Missouri Press.

Misztal, Barbara. 2003. Theories of Social Remembering. Maidenhead, Philadelphia: Open University Press.

Neumann, Birgit. 2008. The Literary Representation of Memory. In A. Erll and A. Nünning (eds). Cultural Memory Studies: An International and Interdisciplinary Handbook (pp. 333-343). Berlin and New York: Walter de Gruyter.

Renza, Louis A. 1980. The Veto of the Imagination: A Theory of Autobiography. In J. Olney (ed.). Autobiography: Essays Theoretical and Critical (pp. 268-295). Princeton, New Jersey: Princeton University Press.

Rigney, Ann. 2008. The Dynamics of Remembrance: Texts Between Monumentality and Morphing. In A. Erll and A. Nünning (eds). Cultural Memory Studies: An International and Interdisciplinary Handbook (pp. 345-353). Berlin and New York: Walter de Gruyter.

Robison, Greg. 2015. Writing the Internment. In C. Parikh and D.Y. Kim (eds). The Cambridge Companion to Asian American Literature (pp. 45-58). Cambridge: Cambridge University Press.

Ruchatz, Jens. 2008. The Photograph as Externalization and Trace. In A. Erll and A. Nünning (eds). Cultural Memory Studies: An International and Interdisciplinary Handbook (pp. 367-378). Berlin and New York: Walter de Gruyter.

Rugg, Linda Haverty. 1997. Picturing Ourselves: Photography and Autobiography. Chicago and London: The University of Chicago Press.

Shackel, Paul A. 2001a. Introduction: The Making of the American Landscape. In P. A. Shackel (ed.). Myth, Memory, and the Making of the American Landscape (pp. 1-13). Gainseville: University Press of Florida.

Shackel, Paul A. 2001b. An Exclusionary Past. In P. A. Shackel (ed.). Myth, Memory, and the Making of the American Landscape (pp. 17-19). Gainseville: University Press of Florida.

Spickard, Paul. 2009. Japanese Americans: The Formation and Transformations of an Ethnic Group. New Jersey: Rutgers University Press.

Uchida, Yoshiko. 1982. Desert Exile: The Uprooting of a Japanese-American Family. Seattle: University of Washington Press.

Weglyn, Michi. 1991. Years of Infamy: The Untold Story of America's Concentration Camps. In J.P. Chan, F. Chin, L. Fusao Inada and S. Wong (eds). The Big Aiiieeeee! An Anthology of Chinese American and Japanese American Literature (pp. 414- 448). New York: Meridian. 
Welzer, Harald. 2008. Communicative Memory. In A. Erll and A. Nünning (eds). Cultural Memory Studies: An International and Interdisciplinary Handbook (pp. 285-298). Berlin and New York: Walter de Gruyter.

Yamamoto, Traise. 1999. Masking Selves, Making Subjects: Japanese American Women, Identity, and the Body. Berkeley and Los Angeles: University of California Press.

Zia, Helen. 2001. Asian American Dreams: The Emergence of an American People. New York: Farrar, Straus and Giroux.

Małgorzata Jarmołowicz-Dziekońska - magister filologii angielskiej, doktorantka na Uniwersytecie w Białymstoku; Studium Języków Obcych Uniwersytetu Medycznego w Białymstoku Adres do korespondencji: margoplus@op.pl 